FACTA UNIVERSITATIS

Series: Physical Education and Sport, Vol. 18, No 2, 2020, pp. 271 - 282

https://doi.org/10.22190/FUPES200713025B

Research article

\title{
AN INVESTIGATION OF SEASONAL VARIATIONS IN THE FITNESS TEST PERFORMANCE OF LAW ENFORCEMENT RECRUITS
}

\author{
UDC $796.012(1-927)$
}

\section{Ashley M. Bloodgood, Matthew R. Moreno, Karly A. Cesario, Megan B. McGuire, Robert G. Lockie}

Department of Kinesiology, California State University, Fullerton, United States

\begin{abstract}
The purpose of this research was to determine whether different seasons could influence fitness test performance in law enforcement recruits. Retrospective examination was conducted on data from four classes, which included 375 recruits (302 males, 73 females) from an agency. The classes were fitness tested during four different seasons in southern California (Fall: $n=89$, temperature $=22-28^{\circ} \mathrm{C}$, humidity $=20-32 \%$; Winter: $n=84$, temperature $=18-26^{\circ} \mathrm{C}$, humidity $=8-11 \%$; Spring: $n=102$, temperature $=22-29^{\circ} \mathrm{C}$, humidity $=23-50 \%$; Summer: $n=100$, temperature $=21-25^{\circ} \mathrm{C}$, humidity $=39-71 \%)$. Fitness testing occurred in the week prior to academy and included: the vertical jump (VJ); push-ups and sit-ups completed in $60 \mathrm{~s}$; and the 20-m multistage fitness test (2OMSFT). A one-way ANOVA was used with Bonferroni post hoc $(p<0.05)$ adjustment to calculate any betweenclass differences. There were no significant between-class differences for the VJ $(p=0.197)$ and sit-ups $(p=0.352)$. Winter and Summer recruits completed $16 \%$ and $19 \%$ significantly more push-up repetitions than Spring recruits $(p \leq 0.029)$. Winter recruits completed $16-22 \%$ significantly more MSFT shuttles than Fall, Spring and Summer classes recruits ( $p \leq 0.009,16 \%, 22 \%$, and 18\%, respectively). Variability in fitness test performance across the seasons may be due to class-to-class fitness variations in recruits. However, recruits in the Winter class were clearly superior in the 20MSFT, which is an aerobic maximal running test. Hotter temperatures can increase cardiovascular strain, while humidity can decrease sweat evaporation rates, which can impact a test such as the 20MSFT. Law enforcement staff may need to consider ambient temperatures and humidity during fitness tests due to potential negative effects on recruit performance.
\end{abstract}

Key words: Ambient Temperature, Humidity, Multistage Fitness Test, Police

Received July 13, 2020 / Accepted August 19, 2020

Corresponding author: Robert George Lockie

Department of Kinesiology, California State University, 800 N. State College Blvd., Fullerton, CA 92831-3599, United States

Phone: + $16572784971 \cdot E-m a i l:$ rlockie@ fullerton.edu

(ㄱ) 2020 by University of Niš, Serbia | Creative Commons License: CC BY-NC-ND 


\section{INTRODUCTION}

Law enforcement can be a physically challenging profession. Occupational tasks include dragging an incapacitated person to safety, engaging in a foot pursuit, and using force to apprehend an offender (Dawes et al., 2017b; Lockie et al., 2018a, Lockie et al., 2020d). Although most of the job entails low-intensity activity (e.g. sitting in a vehicle), these almost sedentary actions can be interspersed with high-intensity activities (e.g. transitioning from sitting in a vehicle to pursuing a suspect on foot) (Anderson, Plecas, \& Segger, 2001; Decker, Orr, Pope, \& Hinton, 2016). Additionally, law enforcement officers typically have little to no control over the environment in which their job must be performed (e.g. patrol areas can be rural or urban, and officers need to work in all weather conditions). As a result of these demands, law enforcement agencies (LEAs) will often conduct fitness testing to measure the physical readiness of recruits prior to hiring. The tests are meant to assess underlying fitness characteristics that contribute to survivability during academy training (Dawes et al., 2019; Lockie et al., 2019a; Shusko et al., 2017), and also underpin job task performance (Dawes et al., 2017a; Lockie et al., 2018a).

Testing during the hiring process (Cesario et al., 2018; Bloodgood et al., in press), or as part of academy training (Lockie et al., 2018a; Lockie, Dawes, Orr, \& Dulla, 2020a), typically occurs on set dates throughout a calendar year. Depending on the facilities available to the LEA, testing may be performed outdoors (Lockie et al., 2018a; Lockie et al., 2019a; Lockie, Dawes, Orr, \& Dulla, 2020a; Lockie et al., 2020b; Lockie et al., 2020c; Lockie et al., in press). Outdoor testing is subject to variable weather conditions which could potentially affect candidate (an individual applying to a LEA) or recruit (an individual hired by a LEA who is completing law enforcement training) performance. Ambient temperatures typically vary during each season, and could have the potential to alter physical performance (Maughan, Otani, \& Watson, 2012; Parkin, Carey, Zhao, \& Febbraio, 1999; Zhao et al., 2013). For example, warmer ambient temperatures can increase heat stress within the body, which decreases time to muscular fatigue (Maughan et al., 2012; Zhao et al., 2013). Cooler ambient temperatures can result in decreased internal body temperature, increased cardiac output, and decreased glycogen utilization (GonzalezAlonso et al., 1999; Parkin et al., 1999). As a result, candidates or recruits who complete fitness testing in cooler temperatures could perform at a higher standard compared to recruits who are tested in warmer conditions.

In addition to ambient temperature, relative humidity could also affect fitness test performance in law enforcement candidates and recruits. Humidity prevents the absorption of sweat from the body, which in turn raises core temperature (GonzalezAlonso et al., 1999). As core temperature rises, the muscles become warmer and can fatigue at a faster rate (Maughan et al., 2012). Fitness tests that include maximal running or stress aerobic capacity may be particularly impacted in humid conditions (Zhao et al., 2013). Accordingly, law enforcement candidates and recruits who perform fitness testing in more humid conditions could be adversely affected compared to recruits who complete their testing in conditions with less humidity. This should be a consideration to LEA staff if candidates need to meet a minimum fitness standard in order to be hired (Brewer, Buckle, \& Castle, 2013). A candidate could suggest that they had less than ideal testing conditions that negatively impacted their chance of employment. Furthermore, during the academy, fitness test performance can be used as a way to reward recruits for their efforts (Lockie et al., 2018a; Lockie et al., 2020a), and in some cases could influence graduation 
rates (Lockie et al., 2019a). Environmental conditions could affect whether a recruit can achieve these accolades. However, there has been no research investigating whether ambient conditions can influence fitness test performance in law enforcement populations.

Collectively, these studies suggest that recruits who complete outdoor fitness testing in cooler temperatures and less humidity (e.g. during the Winter) may have better physical fitness test performance compared to those who complete similar tests in warmer temperatures and more humid conditions (e.g. during the Summer).

The purpose of this research was to ascertain whether seasonal differences in temperature and relative humidity impacted LEA recruit performance during typical law enforcement fitness tests. It was hypothesized that recruits who were tested in the Winter and Fall (Autumn) would performance better than recruits tested in the Summer and Spring.

\section{METHODS}

\section{Participants}

Retrospective examination of data for recruits from four classes from one LEA in the USA was conducted. Data were collected by staff working for the LEA and was released with consent from that organization to the researchers. A convenience sample comprised 375 recruits (age: $27.38 \pm 6.54$ years; height: $1.72 \pm 0.10 \mathrm{~m}$; body mass: $80.17 \pm 14.56 \mathrm{~kg}$ ) was analyzed, which consisted of 302 males (age: $27.17 \pm 6.05$ years; height: $1.75 \pm 0.08 \mathrm{~m}$; body mass: $84.04 \pm 13.16 \mathrm{~kg}$ ) and 73 females (age: $28.26 \pm 8.25$ years; height: $1.61 \pm 0.06$ $\mathrm{m}$; body mass: $64.19 \pm 7.44 \mathrm{~kg}$ ). The characteristics of the participants in this study, in addition to the ratio between males and females, was typical of law enforcement populations (Bloodgood et al., in press; Cesario et al., 2018; Lockie et al., 2018b; Lockie et al., 2020a; Lockie et al., 2020c). Based on the archival nature of this investigation, the institutional ethics committee approved the analysis of pre-existing data (HSR-17-18370). Recruits completed the fitness assessments as part of their physical training for this agency. The study still followed the recommendations of the Declaration of Helsinki (World Medical Association, 1997).

\section{Procedures}

The LEA from this case analysis was located in Southern California where seasonal temperatures remain relatively constant across a year $\left(18^{\circ} \mathrm{C} / 64.4^{\circ} \mathrm{F}-29^{\circ} \mathrm{C} / 84.2^{\circ} \mathrm{F}\right)$. Data from classes from each season within a 10-month period were selected for analysis to cover the four seasons. The Fall class was tested in October 2017. The Winter class was tested in December 2017. The Spring class was tested in May 2018, while the Summer class was tested in June 2018. The researchers had no control of when the classes were conducted as they were part of the regular schedule for the LEA. Accordingly, the classes were selected as they fell within the seasons considered for this study.

The data were collected by staff working on behalf of one LEA. Testing for each class was conducted in the week before the beginning of the training academy. The tests completed were part of a larger battery conducted by the LEA staff (Lockie et al., 2020c). However, as will be explained, the test data selected for this analysis were due to greater applicability across different law enforcement populations. Before testing, the age, height, and body mass of each recruit were chronicled. A portable stadiometer (Seca, 
Hamburg, Germany) was used to measure height; electronic digital scales (Health o Meter, Neosho, Missouri) were utilized to measure body mass. Testing was conducted outdoors on asphalt or concrete surfaces at the LEA facility on a day scheduled by the staff. As described by Lockie et al. (2020c), testing generally occurred between 09:0014:00, and recruits typically did not eat in the 2-3 hours prior to their testing session as they were completing employee-specific paperwork. Recruits rotated through the tests in small groups of 3-4, except for the 20-m multistage fitness test (20MSFT) which was completed in groups of 14-16. Additionally, recruits consumed water as required during testing; no control was placed on how much water was consumed by recruits.

\section{Vertical Jump (VJ)}

The vertical jump (VJ) was selected for analysis as it provides an indirect metric for lower-body power (Lockie et al., 2014a; Lockie, Schultz, Callaghan, \& Jeffriess, 2014b; Lockie et al., 2018b), and has been found to relate to law enforcement-specific tasks (Dawes et al., 2017a), academy survivability (Orr et al., 2016; Dawes, Lockie, Orr, Kornhauser, \& Holmes, 2019), and has been used across different law enforcement populations (Moreno et al., 2019; Myers et al., 2019; Cocke, Dawes, \& Orr, 2016; Crawley, Sherman, Crawley, \& Cosio-Lima, 2016; Orr, Pope, Peterson, Hinton, \& Stierli, 2016; Dawes et al., 2017a; Dawes et al., 2019; Lockie et al., 2020c). A Vertec apparatus (Perform Better, Rhode Island, USA) was employed to measure jump performance with recognized protocols (Lockie et al., 2018b; Lockie et al., 2020c). Initially, the recruit stood side-on to the Vertec (on the recruit's dominant side), reached up and while keeping their heels grounded, displaced as many vanes as possible to establish the zero reference. Then, with no preparatory step or restrictions placed on the range of countermovement, the recruit then jumped as high as they could. Height was recorded from the highest vane that was moved. VJ height was calculated in inches by subtracting the standing reach height from the jump height, and converted to $\mathrm{cm}$. Each recruit completed two trials, with a between-trial rest time of about $60 \mathrm{~s}$, with the best trial analyzed.

\section{Push-ups}

Push-ups were included as a measure of upper-body muscular endurance as better performance in this test has been related to academy survivability (Shusko et al., 2017; Dawes et al., 2019), occupational task performance (Lockie et al., 2018a; Orr, Caust, Hinton, \& Pope, 2018), and is a customary test in law enforcement research across a range of populations (Cocke et al., 2016; Orr et al., 2018; Dawes et al., 2019; Lockie et al., 2019d; Myers et al., 2019; Lockie et al., 2020a). To perform the push-up assessment, recruits completed as many repetitions as they could in $60 \mathrm{~s}$. A tester placed a fist on the floor underneath the recruit's chest to ensure the right depth (Lockie et al., 2019d). Female recruits were always paired with a female tester. To begin the test, the tester began timing with a stopwatch and the recruit lowered themselves by flexing their elbows until their chests contacted the tester's fist. They then extended their elbows to return to the initial position. The recruits completed as many push-ups as possible with this technique in the time period. 


\section{Sit-ups}

Sit-ups were included as a measure of abdominal muscular endurance as they are also a customary test in law enforcement (Cocke et al., 2016; Orr et al., 2018; Dawes et al., 2019; Lockie et al., 2019d; Myers et al., 2019; Lockie et al., 2020a), and have been related to performance in job tasks (Lockie et al., 2018a; Orr et al., 2018). To perform the maximal sit-up test, recruits completed as many repetitions as they could in $60 \mathrm{~s}$. Recruits initially laid on their backs, and flexed their knees to approximately $90^{\circ}$. They were to keep their heels flat on the ground, and their arms crossed over their chest. The feet were then anchored to the ground by a tester. To begin the test, the tester initiated timing with a stopwatch and recruits lifted their shoulders from the ground, and while keeping their arms crossed, touched their elbows to their knees. The recruit then returned towards the start position until their shoulder blades touched the ground. Recruits completed as many repetitions as they could using this technique in the time period.

\section{0-m Multistage Fitness Test (20MSFT)}

The 20MSFT is a standard test of maximal aerobic capacity in different law enforcement groups (Moreno, Lockie, Kornhauser, Holmes, \& Dawes, 2018; Orr et al., 2018; Dawes et al., 2019; Lockie et al., 2020b; Lockie et al., in press). Better aerobic capacity has been related to academy survivability (Shusko et al., 2017; Dawes et al., 2019; Lockie et al., 2019a) and numerous job tasks (Dawes et al., 2017a; Lockie et al., 2018a), and thus was important to include in this study. The 20MSFT was done by recruits on an asphalt surface outdoors, which was the typical venue for this LEA. Recruits ran between two lines spaced $20 \mathrm{~m}$ apart (which were indicated by markers). The running pace for the 20MSFT was standardized by audible cues (i.e. beeps) played from an iPad device (Apple Inc., Cupertino, California) connected to a portable speaker (ION Block Rocker, Cumberland, Rhode Island). The speaker was located in the middle of the testing area in a way that it would not interfere with the recruits. The test was stopped when the recruit was unable to reach the lines twice in a row in accordance with the cues, or by volitional exhaustion. The 20MSFT test was scored according to the final level and stage achieved by the recruit, with the level and stage data used to calculate the final number of shuttles completed.

\section{Statistical Analysis}

Statistical analyses were computed using the Statistics Package for Social Sciences (Version 25.0; IBM Corporation, New York, USA). Descriptive statistics (means and standard deviation [SD]) were calculated for each variable. A one-way analysis of variance (ANOVA), with Bonferroni post hoc adjustment for multiple pairwise comparisons, was used to derive any differences between the four classes. The one-way ANOVA was used due to robustness of this analysis and the size of the sample (Gamage \& Weerahandi, 1998; Lockie, Dawes, Kornhauser, \& Holmes, 2019b; Lockie et al., 2020a). Significance was set at $p<0.05$ a priori. Within each class, the sexes were combined for this analysis. This approach has been adopted in previous law enforcement and police research (Cesario et al., 2018; Lockie et al., 2018a; Lockie et al., 2019b; Lockie et al., 2020c). 


\section{RESULTS}

Mean temperatures and humidity levels across the testing times for each day for each class were retrieved from the National Weather Service database (https://www.weather.gov/). This can be viewed in Table 1. Despite the temperatures being similar, humidity levels between the seasons varied, with Summer having the highest humidity levels (39-71\%) and Winter having the lowest humidity levels (8-11\%). Table 2 shows the data for all the classes. The Fall class had 71 males and 18 females, while the Winter class had 73 males and 11 females. The Spring had 75 males and 27 females, and the Summer class had 83 males and 17 females. There were no significant between-class differences for age $(p=0.203)$ and body mass $(p=0.479)$. The Fall class was significantly taller than the Spring $(p=0.001)$ and Summer $(p=0.004)$ classes, but not the Winter class $(p=0.320)$.

Table 1 Ambient temperatures and humidity percentages across the four seasons on the testing days

\begin{tabular}{lrrrc}
\hline & Fall & Winter & Spring & Summer \\
\hline Temperature $\left({ }^{\circ} \mathrm{C}\right)$ & $22-28$ & $18-26$ & $22-29$ & $21-25$ \\
Humidity $(\%)$ & $20-30$ & $8-11$ & $23-50$ & $39-71$ \\
\hline
\end{tabular}

Table 2 Descriptive data (mean \pm SD) age, height, body mass, and fitness test performance between classes conducted in different seasons

\begin{tabular}{lcccc}
\hline & $\begin{array}{c}\text { Fall } \\
(\mathrm{N}=89)\end{array}$ & $\begin{array}{c}\text { Winter } \\
(\mathrm{N}=84)\end{array}$ & $\begin{array}{c}\text { Spring } \\
(\mathrm{N}=102)\end{array}$ & $\begin{array}{c}\text { Summer } \\
(\mathrm{N}=100)\end{array}$ \\
\hline Age (years) & $28.37 \pm 6.91$ & $27.89 \pm 7.73$ & $26.88 \pm 6.43$ & $26.59 \pm 4.99$ \\
Height (m) & $1.76 \pm 0.09$ & $1.73 \pm 0.09$ & $1.71 \pm 0.10^{*}$ & $1.72 \pm 0.10^{*}$ \\
Body Mass (kg) & $79.78 \pm 14.89$ & $81.76 \pm 14.00$ & $78.57 \pm 14.45$ & $80.82 \pm 14.86$ \\
Vertical Jump (cm) & $51.49 \pm 12.89$ & $54.20 \pm 12.30$ & $53.33 \pm 14.75 \S \phi$ & $55.58 \pm 12.64$ \\
Push-ups (no.) & $41.21 \pm 16.02$ & $45.16 \pm 13.41 *$ & $38.54 \pm 15.38$ & $44.99 \pm 17.78^{*}$ \\
Sit-ups (no.) & $35.06 \pm 8.62$ & $35.79 \pm 10.17$ & $36.66 \pm 12.94$ & $37.71 \pm 9.77$ \\
20MSFT (shuttles) & $52.86 \pm 20.31 \S$ & $61.69 \pm 17.98$ & $49.62 \pm 16.72 \S$ & $51.68 \pm 17.50 \S$ \\
\hline Legend: * Significantly $(p<0.05)$ different from the Fall class; $\S$ Significantly $(p<0.05)$ different from the \\
\multicolumn{4}{c}{ Winter class; $\phi$ Significantly $(p<0.05)$ different from the Summer class. }
\end{tabular}

There were no significant differences between the classes for the VJ $(p=0.197)$ and sit-up test $(p=0.352)$. For push-ups, recruits in the Winter and Summer completed $16 \%$ and $19 \%$ significantly more repetitions than recruits in the Spring $(p=0.029$ and 0.024 , respectively). Recruits in the Winter completed $16 \%, 22 \%$, and $18 \%$ significantly more MSFT shuttles than recruits in the Fall $(p=0.009)$, Spring $(p<0.001)$, and Summer $(p=0.001)$ classes, respectively.

\section{DISCUSSION}

This study provided a preliminary investigation as to whether there were seasonal variations in the fitness test performance of recruits from one LEA. Anecdotally, there appear to be few LEAs that take a record of ambient temperature and humidity during testing or training sessions. This is despite the fact that ambient temperature (Kruk, Pekkarinen, Manninen, \& Hanninen, 1991; Guy, Deakin, Edwards, Miller, \& Pyne, 2015) 
and humidity (Maughan et al., 2012; Zhao et al., 2013) can negatively impact physical performance. Different ambient temperature and humidity could affect the physical performance of candidates and recruits and influence how successful they are in completing fitness tests and exercises. The results detailed that there were select disparities in the fitness tests selected for analysis in this study among classes conducted in different seasons. The Winter and Summer recruits completed more push-ups than the Spring recruits, while the Winter recruits completed more 20MSFT shuttles than all the other classes. While these results may have been in part due to the variation in fitness test performance that can be seen across different law enforcement recruit classes (Lockie et al., 2018c; Lockie et al., 2018d; Lockie et al., 2020a), the 20MSFT results have important implications for LEA training staff.

There were no significant disparities between the four classes in age and body mass. However, the Fall class had a mean height that was significantly taller than the Spring and Summer classes. As the human resources department of a LEA generally controls the intake of recruits to a particular class, there can be a wide variety of recruits allocated to academy classes (Lockie et al., 2020a). Nonetheless and as stated, the characteristics of all classes was typical of law enforcement populations from the literature (Cesario et al., 2018; Lockie et al., 2018b; Lockie et al., 2020a; Lockie et al., 2020c; Bloodgood et al., in press). Thus, specific to the LEA analyzed in this study, it can be stated that all recruit classes were typical of previous classes. Accordingly, the results from the analysis of the seasonal variations in the fitness tests has application across law enforcement recruits.

The most notable results for this study concerned the 20MSFT. The recruits from the Winter class completed significantly more shuttles than recruits from all other classes. Previous research has shown that increases in ambient temperature have a significant effect on aerobically-based tasks (Ely, Cheuvront, Kenefick, \& Sawka, 2010; Zhao et al., 2013). Performing aerobic-based exercise in warmer temperatures results in a gradual slowing of pace and a reduced ability to produce a final burst of energy to complete a task (Ely et al., 2010). A rise in thermoregulatory skin flow, which increases with hotter ambient temperatures, exacerbates cardiovascular strain, which adversely impacts a recruit's ability to withstand the demands of continuous aerobic exercise (Periard, Caillaud, \& Thompson, 2012). Hotter ambient temperatures can also lead to dehydration with insufficient fluid intake (Gonzalez, Calbet, \& Nielsen, 1999; Jones, Cleary, Lopez, Zuri, \& Lopez, 2008; Zhao et al., 2013). Dehydration, in conjunction with a rise in skin temperature, impairs aerobic capacity, which is decreased incrementally with warmer skin temperature (Sawka, Cheuvront, \& Kenefick, 2012). Not only does a rise in skin temperature affect performance, but also a rise in core body temperature. Higher core temperatures can lead to a reduction in motor drive performance during aerobic exercise (Nielsen, Savard, Richter, Hargreaves, \& Saltin, 1990). Collectively, these results could highlight some of the reasons why the recruits from the Winter class performed significantly better in the 20MSFT than the other classes. LEA training personnel should be cognizant of the resultant weather-related influences on aerobic fitness test performance, which could produce lower test scores and performance in warmer seasons. It is possible that given the relationships between the 20MSFT with longer distance runs such over $2.4 \mathrm{~km}$ (Lockie et al., 2020b; Lockie et al., in press), and shorter distance runs over $300 \mathrm{~m}$ (Moreno et al., 2018), if recruits perform more poorly in the 20MSFT in warmer and more humid conditions, they would also do so in the other running tasks. This could affect candidate performance during the hiring process if they complete outdoor running tests, and recruit performance in physical training sessions. 
For push-ups, recruit classes in the Winter and Summer performed better than the Spring class. The Winter group's superior performance could be in part attributed to the cooler ambient temperatures $\left(18-26^{\circ} \mathrm{C}\right)$ and lower humidity levels $(8-11 \%)$. As discussed previously, the cooler temperature may have been a result of lower core body temperatures which allowed recruits to decrease their rate of fatigue (Gonzalez-Alonso et al., 1999; Parkin et al., 1999). While Spring's humidity was lower than Summer's, the Spring session had a higher peak ambient temperature $\left(29^{\circ} \mathrm{C}\right)$ compared to Summer $\left(25^{\circ} \mathrm{C}\right)$. This may not be typical of other parts of the USA, but is not uncommon in southern California. Muscular endurance tests, such as the 60-s push-up test, have been associated with cardiorespiratory fitness (Vaara et al., 2012; Cesario et al., 2018). Research has shown that cardiorespiratory capacity decreases as ambient temperature increases (Zhao et al., 2013), which could partially explain the decrement in push-up performance. Although the natural variation that occurs in recruit classes could also contribute to these results (Lockie et al., 2018c; Lockie et al., 2018d; Lockie et al., 2020a), LEA training staff should recognize that ambient temperature may impact maximal push-up performance.

There were no differences in performance observed between all four seasons for sit-ups. The VJ is a lower-body power test (Lockie et al., 2014b; Lockie et al., 2018b), and its short duration and dependence on the stretch-shortening cycle of the muscles (Marković, Dizdar, Jukić, \& Cardinale, 2004) may contribute to why it is less impacted by variations in temperature and humidity. This may be especially true in a climate such as southern California. The sit-ups results could be in part due to the ability for the recruit to rest in the supine position before continuing on with the test. This could limit the effects of any temperature or humidity-related fatigue to manifest, which may have occurred for the push-up test. Indeed, during the push-up test, recruits were not allowed to drop their knees to rest. Sex disparities may also be less in the sit-up test compared to the push-up test (Ryman Augustsson et al., 2009). This could mean any disparities in upper-body strength (Bloodgood et al., in press; Cesario et al., 2018; Lockie et al., 2019d; Lockie et al., 2020a) and tolerance to environmental stressors (Burse, 1979) may be lessened for female recruits, limiting variation across the seasons. Although these suggestions are somewhat speculative, the current data suggests that abdominal muscular endurance measured by sit-ups, and lower-body power measured by the VJ, were less affected by ambient temperature and humidity.

There are limitations to this research that should be documented. Ambient temperature and humidity were not directly measured during each class, so the values collected retrospectively may not have been exactly what recruits experienced on their day of testing. Due to scheduling, recruits were also tested at different times of the day. Although typical for this agency due to recruit class size (Lockie et al., 2018b; Lockie et al., 2019c; Lockie et al., 2020b; Lockie et al., 2020c Lockie et al., in press), this meant different recruits experienced different ambient conditions, even though they were tested in the same season. Further, different surfaces used for exercise can influence the temperature experienced by individuals (Petrass, Twomey, Harvey, Otago, \& LeRossignol, 2015), and this was not considered in this study. Hydration was not controlled during testing, which although typical for this LEA (Lockie et al., 2018b; Lockie et al., 2020c), could have affected the fitness test performance of recruits. The temperatures and humidity presented were specific to the Los Angeles County region of southern California. This region tends to be more temperate than other parts of the USA, which is evidenced by the consistent temperatures across the seasons (although humidity did vary). These results were from fitness testing sessions, and not from physical training sessions. Even though it could be expected that 
performance in aerobic-based exercises during physical training could show similar decrements similar to that for the 20MSFT across the seasons, this cannot be confirmed from the results of this study. This would be worthy of further analysis, especially if certain agencies use performance in physical training sessions as part of their graduation requirements (Lockie et al., 2019a).

\section{CONCLUSION}

In conclusion, the study results suggested that ambient temperature and humidity could influence performance in upper-body muscular endurance (push-ups) and aerobic fitness (20MSFT) tests. Lower-body power (VJ) and abdominal muscular endurance (situps) appeared to be less affected by seasonal changes in ambient temperature and humidity. The variation that commonly occurs between law enforcement recruit classes could have influenced these results. Nevertheless, the fact that the Winter class was clearly superior in the 20MSFT has important implications for LEA training staff. It can be surmised from the current data detailed that aerobic fitness tests and exercise performance could be influenced by ambient temperature and humidity. Training staff should recognize that poorer performance in hotter and more humid conditions could affect potential employment if an aerobic fitness test is completed outdoors in different seasons, in addition to potentially poorer performance in physical training sessions.

Acknowledgments: This research project received no external financial assistance. None of the authors have any conflict of interest. The authors would like to thank the training instructors for facilitating this research, and the California State University, Fullerton tactical research team for collating the data.

\section{REFERENCES}

Anderson, G.S., Plecas, D., \& Segger, T. (2001). Police officer physical ability testing - Re-validating a selection criterion. Policing: An International Journal of Police Strategies and Management, 24(1), 8-31.

Bloodgood, A.M., Dawes, J.J., Orr, R.M. Stierli, M., Cesario, K.A., Moreno, M.R., Dulla, J.M., et al. (in press). Effects of sex and age on physical testing performance for law enforcement agency candidates: Implications for academy training. Journal of Strength and Conditioning Research, doi:10.1519/ jsc.0000000000003207.

Brewer, J., Buckle, P., \& Castle, P. (2013). The use of work place physiological measurements to establish the minimum fitness standards required for entry into the United Kingdom Police Service. Journal of Athletic Enhancement, 2, doi:10.4172/2324-9080.1000121.

Burse, R.L. (1979). Sex differences in human thermoregulatory response to heat and cold stress. Human Factors, 21(6), 687-699.

Cesario, K.A., Dulla, J.M., Moreno, M.R., Bloodgood, A.M., Dawes, J.J., \& Lockie, R.G. (2018). Relationships between assessments in a physical ability test for law enforcement: Is there redundancy in certain assessments? International Journal of Exercise Science, 11(4), 1063-1073.

Cocke, C., Dawes, J., \& Orr, R.M. (2016). The use of 2 conditioning programs and the fitness characteristics of police academy cadets. Journal of Athletic Training, 51(11), 887-896.

Crawley, A.A., Sherman, R.A., Crawley, W.R., \& Cosio-Lima, L.M. (2016). Physical fitness of police academy cadets: Baseline characteristics and changes during a 16-week academy. Journal of Strength and Conditioning Research, 30(5), 1416-1424.

Dawes, J.J., Lindsay, K., Bero, J., Elder, C., Kornhauser, C., \& Holmes, R. (2017a). Physical fitness characteristics of high vs. low performers on an occupationally specific physical agility test for patrol officers. Journal of Strength and Conditioning Research, 31(10), 2808-2815. 
Dawes, J.J., Lockie, R.G., Orr, R.M., Kornhauser, C., \& Holmes, R.J. (2019). Initial fitness testing scores as a predictor of police academy graduation. Journal of Australian Strength and Conditioning, 27(4), 30-37.

Dawes, J.J., Orr, R.M., Flores, R.R., Lockie, R.G., Kornhauser, C., \& Holmes, R. (2017b). A physical fitness profile of state highway patrol officers by gender and age. Annals of Occupational and Environmental Medicine, 29(1), 16.

Decker, A., Orr, R.M., Pope, R., \& Hinton, B. (2016). Physiological demands of law enforcement occupational tasks in Australian police officers. Journal of Australian Strength and Conditioning, 24, 78-79.

Ely, B., Cheuvront, S., Kenefick, R., \& Sawka, M. (2010). Aerobic performance is degraded, depsite modest hypothermia, in hot environments. Medicine and Science in Sports and Exercise, 42(1), 135-41.

Gamage, J., \& Weerahandi, S. (1998). Size performance of some tests in one-way ANOVA. Communications in Statistics - Simulation and Computation, 27(3), 625-640.

Gonzalez-Alonso, J., Teller, C., Andersen, S.L., Jensen, F.B., Hyldig, T., \& Nielsen, B. (1999). Influence of body temperature on the development of fatigue during prolonged exercise in the heat. Journal of Applied Physiology, 86(3), 1032-1039.

Gonzalez, A., Calbet, J., \& Nielsen, B. (1999). Metabolic and thermodynamic responses to dehydration induced reductions in muscle blood flow in exercising humans. Journal of Physiology, 520(2), 577-589.

Guy, J.H., Deakin, G., Edwards, A., Miller, C., \& Pyne, D. (2015). Adaptation to hot environmental conditions: An exploration of the performance basis, procedures and future directions to optimise opportunitites for elite athletes Sports Medicine, 45(3), 303-311.

Jones, L., Cleary, M., Lopez, R., Zuri, R., \& Lopez, R. (2008). Active dehydration impairs upper and lower body anaerobic muscular power. Journal of Strength and Conditioning Research, 22(2), 455-463.

Kruk, B., Pekkarinen, K., Manninen, K., \& Hanninen, O. (1991). Comparison in men of physiological responses to exercise of increasing intensity at low and moderate ambient temperatures. European Journal of Applied Physiology, 62(5), 353-357.

Lockie, R.G., Callaghan, S.J., Berry, S.P., Cooke, E.R., Jordan, C.A., Luczo, T.M., et al. (2014a). Relationship between unilateral jumping ability and asymmetry on multidirectional speed in team-sport athletes. Journal of Strength and Conditioning Research, 28(12), 3557-3566.

Lockie, R.G., Schultz, A.B., Callaghan, S.J., \& Jeffriess, M.D. (2014b). The effects of traditional and enforced stopping speed and agility training on multidirectional speed and athletic performance. Journal of Strength and Conditioning Research, 28(6), 1538-1551.

Lockie, R.G., Dawes, J.J., Balfany, K., Gonzales, C.E., Beitzel, M.M., Dulla, J.M., et al. (2018a). Physical fitness characteristics that relate to Work Sample Test Battery performance in law enforcement recruits. International Journal of Environmental Research and Public Health, 15(11), 2477.

Lockie, R.G., Dawes, J.J., Orr, R.M., Stierli, M., Dulla, J.M., \& Orjalo, A.J. (2018b). An analysis of the effects of sex and age on upper- and lower-body power for law enforcement agency recruits prior to academy training. Journal of Strength and Conditioning Research, 32(7), 1968-1974.

Lockie, R.G., Fazilat, B., Dulla, J.M., Stierli, M., Orr, R.M., Dawes, J.J., et al. (2018c). A retrospective and comparative analysis of the physical fitness of custody assistant classes prior to academy training. Sports and Exercise Medicine Open Journal, 4(1), 44-51.

Lockie, R.G., Stierli, M., Dawes, J.J., Cesario, K.A., Moreno, M.R., Bloodgood, A.M., et al. (2018d). Are there similarities in physical fitness characteristics of successful candidates attending law enforcement training regardless of training cohort? Journal of Trainology, 7(1), 5-9.

Lockie, R.G., Balfany, K., Bloodgood, A.M., Moreno, M.R., Cesario, K.A., Dulla, J.M., et al. (2019a). The influence of physical fitness on reasons for academy separation in law enforcement recruits. International Journal of Environmental Research and Public Health, 16(3), 372.

Lockie, R.G., Dawes, J.J., Kornhauser, C.L., \& Holmes, R.J. (2019b). Cross-sectional and retrospective cohort analysis of the effects of age on flexibility, strength endurance, lower-body power, and aerobic fitness in law enforcement officers. Journal of Strength and Conditioning Research, 33(2), 451-458.

Lockie, R.G., Moreno, M.R., Cesario, K.A., McGuire, M.B., Dawes, J.J., Orr, R.M., et al. (2019c). The effects of aerobic fitness on day one physical training session completion in law enforcement recruits. Journal of Trainology, 8(1), 1-4.

Lockie, R.G., Orr, R.M., Stierli, M., Cesario, K.A., Moreno, M.R., Bloodgood, A.M., et al. (2019d). The physical characteristics by sex and age for custody assistants from a law enforcement agency. Journal of Strength and Conditioning Research, 33(8), 2223-2232.

Lockie, R.G., Dawes, J.J., Orr, R.M., \& Dulla, J.M. (2020a). Recruit fitness standards from a large law enforcement agency: Between-class comparisons, percentile rankings, and implications for physical training. Journal of Strength and Conditioning Research, 34(4), 934-941. 
Lockie, R.G., Hernandez, J.A., Moreno, M.R., Dulla, J.M., Dawes, J.J., \& Orr, R.M. (2020b). 2.4-km run and 20-m multistage fitness test relationships in law enforcement recruits after academy training. Journal of Strength and Conditioning Research, 34(4), 942-945.

Lockie, R.G., Ruvalcaba, T.R., Stierli, M., Dulla, J.M., Dawes, J.J., \& Orr, R.M. (2020c). Waist circumference and waist-to-hip ratio in law enforcement agency recruits: Relationship to performance in physical fitness tests. Journal of Strength and Conditioning Research, 34(6), 1666-1675.

Lockie, R.G., Bloodgood, A., Moreno, M., McGuire, M., Balfany, K., \& Dawes, J. (2020d). Training load demands measured by surface electromyography wearable technology when performing law enforcementspecific body drags. Facta Universitatis Series Physical Education and Sport, 18(1), 1-12.

Lockie, R.G., Dawes, J.J., Moreno, M.R., Cesario, K.A., Balfany, K., Stierli, M., Dulla, J.M., \& Orr, R.M. (in press). Relationship between the 20-m multistage fitness test and 2.4-km run in law enforcement recruits. Journal of Strength and Conditioning Research doi:10.1519/jsc.0000000000003217.

Marković, G., Dizdar, D., Jukić, I., \& Cardinale, M. (2004). Reliability and factorial validity of squat and countermovement jump tests. Journal of Strength and Conditioning Reseach, 18(3), 551-555.

Maughan, R., Otani, J., \& Watson, H. (2012). Influence of relative humidity on prolonged exercise capacity in a warm environment. European Journal of Applied Physiology, 112(6), 2313-2321.

Moreno, M.R., Dulla, J.M., Dawes, J.J., Orr, R.M., Cesario, K.A., \& Lockie, R.G. (2019). Lower-body power and its relationship with body drag velocity in law enforcement recruits. International Journal of Exercise Science, 12(4), 847-858

Moreno, M.R., Lockie, R.G., Kornhauser, C.L., Holmes, R.J., \& Dawes, J.J. (2018). A preliminary analysis of the relationship between the multistage fitness test and 300-m run in law enforcement officers: Implications for fitness assessment. International Journal of Exercise Science, 11(4), 730-738.

Myers, C.J., Orr, R.M., Goad, K.S., Schram, B.L., Lockie, R., Kornhauser, C., et al. (2019). Comparing levels of fitness of police officers between two United States law enforcement agencies. Work, 63(4), 615-622.

Nielsen, B., Savard, G., Richter, E., Hargreaves, M., \& Saltin, B. (1990). Muscle blood flow and muscle metabolism during exercise and heat stress. Journal of Applied Physiology, 69(3), 1040-1046.

Orr, R., Pope, R., Peterson, S., Hinton, B., \& Stierli, M. (2016). Leg power as an indicator of risk of injury or illness in police recruits. International Journal of Environmental Research and Public Health, 13(2), 237.

Orr, R.M., Caust, E., Hinton, B., \& Pope, R. (2018). Selecting the best of the best: Associations between anthropometric and fitness assessment results and success in police specialist selection. International Journal of Exercise Science, 11(4), 785-796.

Parkin, J., Carey, M., Zhao, S., \& Febbraio, M. (1999). Effect of ambient temperature on human skeletal muscle metabolism during fatiguing submaximal exercise Journal of Applied Physiology, 86(3), 902-908.

Periard, J., Caillaud, C., \& Thompson, M. (2012). The role of aerobic fitness and exercise intensity on endurance perfomrance in uncompensable heat stress conditions. European Journal of Applied Physiology, 112(6), 1989-1999.

Petrass, L.A., Twomey, D.M., Harvey, J.T., Otago, L., \& LeRossignol, P. (2015). Comparison of surface temperatures of different synthetic turf systems and natural grass: Have advances in synthetic turf technology made a difference. Proceedings of the Institution of Mechanical Engineers, Part P: Journal of Sports Engineering and Technology, 229(1), 10-16.

Ryman Augustsson, S., Bersås, E., Magnusson Thomas, E., Sahlberg, M., Augustsson, J., \& Svantesson, U. (2009). Gender differences and reliability of selected physical performance tests in young women and men. Advances in Physiotherapy, 11(2), 64-70.

Sawka, M., Cheuvront, S., \& Kenefick, R. (2012). High skin temperature and hypohydration impair aerobic performance. Experimental Physiology, 97(3), 327-332.

Shusko, M., Benedetti, L., Korre, M., Eshleman, E.J., Farioli, A., Christophi, C.A., et al. (2017). Recruit fitness as a predictor of police academy graduation. Occupational Medicine, 67(7), 555-561.

Vaara, J.P., Kyrolainen, H., Niemi, J., Ohrankammen, O., Hakkinen, A., Kocay, S., et al. (2012). Associations of maximal strength and muscular endurance test scores with cardiorespiratory fitness and body composition. Journal of Strength and Conditioning Research, 26(8), 2078-2086.

World Medical Association. (1997). World Medical Association declaration of Helsinki. Recommendations guiding physicians in biomedical research involving human subjects. Journal of the American Medical Association, 277, 925-926.

Zhao, J., Lorenzo, S., An, N., Feng, W., Lai, L., \& Cui, S. (2013). Effects of heat and different humidity levels on aerobic and anaerobic exercise performance in athletes Journal of Exercise Science and Fitness, 11(1), $35-41$. 


\section{ISTRAŽIVANJE SEZONSKIH VARIJACIJA FITNES PERFORMANSI REGRUTA POLICIJSKIH SNAGA}

Svrha ovog istraživanja bila je da se utvrdi da li različita godišnja doba mogu da utiču na fitnes performanse regruta policije. Retrospektivno istraživanje obavljeno je na osnovu podataka iz četiri klase u koje je uključeno 375 regruta (302 muškarca, 73 žene). Klase regruta su testirane tokom četiri različita sezonska doba u južnoj Kaliforniji (jesen: $n=89$, temperatura $=22-28^{\circ} \mathrm{C}$, vlaga $a=20-32 \%$; zima: $n=84$, temperatura $=18-26^{\circ} \mathrm{C}$, vlažnost $=8-11 \%$; proleće: $n=102$, temperatura $=22-29^{\circ} \mathrm{C}$, vlažnost $=23-50 \%$; leto: $n=100$, temperatura $=21-25^{\circ} \mathrm{C}$, vlažnost $=39-71 \%$ ). Ispitivanje performansi fitnesa je obavljeno tokom nedelje pre akademije i obuhvatalo je: vertikalni skok (VS); sklekove i trbušnjake izvedene za $60 \mathrm{~s}$; $i$ 20-metarski beep fitnes test (20MSFT). Korišćena je one-way ANOVA sa Bonferroni post hoc ( $p<0.05$ ) metodom u cilju utvrđivanja međuklasnih razlika. Nisu utvrđene statistički značajne razlike za VS $(p=0.197)$ i trbušnjake $(p=0.352)$. Zimski i letnji regruti su uradilii značajno više sklekova od proljetnih regruta $(p \leq 0.029,16 \%$ i 19\%, tim redosledom). Zimski regruti su istrčaki značajno više $20 M S F T$ deonica od regruta iz jesenjih, prolećnih i letnjih klasa ( $\leq \leq 0.009,16 \%, 22 \%$, i 18\%, tim redosledom). Promenljivost u performansama fitnesa tokom godišnjeg doba može da bude posledica varijacija između klasa regruta. Ipak, regruti zimske klase bili su očigledno superiorniji u 20MSFT, koji predstavlja aerobni test maksimalnog trčanja. Niže temperature mogu da povećaju kardiovaskularno naprezanje, dok vlaga može da smanji stopu isparavanja znoja, što može da utiče na test kao što je 20MSFT. Pripadnici policije će možda morati da uzmu u obzir temperaturu i vlažnost vazduha tokom testova fitnesa zbog potencijalnih negativnih efekata na rezultate testova.

Ključne reči: temperatura vazduha; vlažnost; beep fitnes test; policija 